\title{
An Annotated Bibliography of Items Relating to Collection Evaluation in Academic Libraries, 1969-1981
}

This annotated bibliography concerning collection evaluation in academic libraries focuses on (1) case studies of evaluation projects, (2) newly proposed techniques, (3) attempts to define adequacy in a collection, and (4) overviews of the evaluation process, all published from 1969 to the present.

I $I_{N}$ THE 1980s climate of budgetary constraint, academic libraries more than ever must confront the problem of collection evaluation, in order to be certain that collections are developed as rationally and efficiently as possible, given available resources. As a working bibliographer, the author has found Signe Ottersen's “A Bibliography on Standards for Evaluating Libraries" [College \& Research Libraries 32:127-44 (1971)] extremely helpful. Because the coverage of the Ottersen bibliography ends with 1969 , a supplement from that date to the present is highly desirable. The present bibliography attempts, in part, to meet that purpose. It focuses on English-language items concerning collection evaluation and collection standards (which constitute one method of evaluation) published since 1969. Unlike Ottersen, material concerning library evaluation and standards in general has not been included unless a significant portion of a particular item deals with collections.

This bibliography concentrates on material relevant to university and college libraries. Studies dealing exclusively with twoyear college, public, special, or secondary

Thomas E. Nisonger is coordinator for collection development and head, Acquisitions Department, McDermott Library, University of Texas at Dallas. Most of the work on this project was completed between January and June 1980, when the compiler was on official study leave from his position as a bibliographer at the University of Manitoba. school libraries have been disregarded except when an especially noteworthy evaluation technique is discussed. Even though they contain much useful information, unpublished items (e.g., reports of the Collection Analysis Project) have been excluded due to limitations of space and because they are generally less accessible to the reader. Doctoral dissertations are included, while master's theses and letters to the editors of journals are not.

An effort has been undertaken to locate the following types of items: (1) case studies of evaluation projects; (2) newly proposed evaluation techniques; (3) overviews of the collection evaluation process; (4) attempts to delineate what constitutes an adequate collection; (5) commentary on standards for evaluation; and (6) miscellaneous material of practical or theoretical interest. One should bear in mind that this is not a comprehensive bibliography but a selection of the most useful contributions. Many of the entries were accompanied by abstracts. However, in all cases original annotations have been written which point out features especially relevant to the evaluation of collections.

Finally, it is evident that no universal agreement exists concerning several key questions in the area of collection evaluation, such as, What is the most efficacious evaluation technique? How does one define collection adequacy? Are quantitative or qualitative methods preferable? Should holdings or delivery capacity be stressed? and Which 
standards, if any, are valid? For this reason, collection evaluation is an intriguing and important topic on which further speculative thought and research is necessary.

Alexander, Norman Dale. "A Suggested Model, Designed to Serve as a Guide for Evaluating the Adequacy of Academic Library Collections in American Colleges and Universities." Ph.D. dissertation, Univ. of Southern California, 1976.

The model considers six factors: (1) total units held; (2) number of periodical subscriptions; (3) quality of units held; (4) quality of periodicals; (5) annual additions; and (6) percentage of the institution's budget spent on library materials. It is applied to fifty-five academic libraries in the Pacific Northwest.

Allen, G. G., and Eichinski, G. "An Estimate of Inadequacies in Library Budgets and Stock in Colleges of Advanced Education," Australian Academic and Research Libraries 2:168-71 (1971).

Data from twenty Australian college libraries covering acquisitions budgets, holdings, and staff is compared with the 1960 Australian standards. The cost of rectifying the deficits is estimated.

Allen, G. G., and Eichinski, G. "The Need Cries Out: Inadequacy of Library Collections and Budgets in Colleges of Advanced Education," Australian Journal of Higher Education 4:157-61 (1971).

At no point in Australian history has a college of advanced education library met the Commonwealth Advisory Committee on Advanced Education's provisional standard of fifty books per FTE student and one and onehalf subscriptions per FTE student.

American Library Association. Resources and Technical Services Division. Collection Development Committee. "Guidelines for the Evaluation of the Effectiveness of Library Collections," in David L. Perkins, ed., Guidelines for Collection Development, p.9-19. Chicago: American Library Assn., 1979.

Employing a checklist format, this document lists the advantages and disadvantages relating to several of the major approaches to collection evaluation. It is concluded that a combination of methods should be employed.

Ash, Joan, and Morgan, James E. “Journal Evaluation Study at the University of Connecticut Health Center," Bulletin of the Medical Library Association 65:297-99 (1977).

Approximately one-sixth of 3,000 periodical titles were canceled as a result of this project. The primary criteria were coverage by Index Medicus, photocopying record, and faculty opinion, in addition to cost factors, reference use, citation studies, and holdings of nearby libraries.

Association of College and Research Libraries. "Draft: Standards for College Libraries, 1975 Revision," College \& Research Libraries News 35:284-86, 299-305 (1974).

The section on collections emphasizes the need for holdings in all formats. A formula for print material begins with a base of 85,000 volumes. Libraries are rated from $A$ to $D$.

Association of College and Research Libraries. "An Evaluative Checklist for Reviewing a College Library Program," College \& Research Libraries News 40:305-16 (1979).

This checklist, approved by the ACRL Board in June 1979, supplements the "Standards for College Libraries," adopted in 1975. The library is evaluated by applying a one-to-twelve scale to thirty-two questions, organized into the standards' eight major headings.

Association of College and Research Libraries. "Standards for College Libraries," College \& Research Libraries News $36: 277-79,290-301$ (1975).

The final draft, which replaces the 1959 "standards," was approved by the ACRL in July 1975. It contains no significant alterations with regard to collections.

Association of Research LibrariesAssociation of College and Research Libraries. Committee on University Library Standards. "Draft: Standards for University Libraries," College \& Research Li- 
braries News 39:89-99 (1978).

Standard $B$ asserts that the collection should: (1) be adequate to support the university's instructional and research programs; (2) be developed according to a systematic plan; and (3) contain recorded information in all available formats. A methodological appendix contains an explanation of Cartter's Library Resources Index with applications to twenty university libraries.

\section{Association of Research Libraries-} Association of College and Research Libraries. Committee on University Library Standards. "Standards for University Libraries," College \& Research Libraries News 40:101-10 (1979).

This final document was approved by the ARL in October 1978 and the ACRL in January 1979. The three standards on collections were not changed, but their order was rearranged.

Axford, H. William. "An Approach to Performance Budgeting at the Florida Atlantic University Library," College \& Research Libraries 32:87-104 (1971).

A reorganization of the Florida Atlantic University library led to the development of a performance-budgeting model for the state university system of Florida. In regard to collections, the Clapp-Jordan formula was rejected in favor of a modified version of the Washington State formula.

Black, George W., Jr. "Estimating Collection Size Using the Shelf List in a Science Library," Journal of Academic Librarianship 6:339-41 (1981).

A method developed at Southern Illinois University, for estimating the monographic holdings in different science subject areas by measuring the shelflist, is presented.

Bolgiano, Christina E., and King, Mary Kathryn. "Profiling a Periodicals Collection," College \& Research Libraries 39:99-104 (1978).

The methods used to evaluate the periodical holdings at James Madison University, Harrisonburg, Virginia, included: checking the Farber and Katz lists plus citations from master's theses, determining the number of titles supporting each department, and ana- lyzing interlibrary loan transactions.

Bonk, Wallace John, and Magrill, Rose Mary. "Collection Evaluation," in their Building Library Collections. 5th ed., p. 305-13. Metuchen, N.J.: Scarecrow, 1979.

The student is introduced to the basic methods of collection evaluation. To evaluate any type of collection, information concerning three factors is necessary: (1) the materials held; (2) the community served; and (3) the purposes of the collection.

Bonn, George S. "Evaluation of the Collection," Library Trends 22:265-304 (1974).

A comprehensive survey of the methods used in collection evaluation in academic libraries is offered along with extensive references to the appropriate literature.

Bonn, George S. "Library Self-Surveys," $L i$ brary and Information Science, no.9: 115-21 (1971).

Outlines a checklist of points that should be covered in a comprehensive library survey. Also discusses comparison of circulation with holdings by subject area and how to examine the journal collection.

Bowden, Virginia M. "Comparative Analysis of Health Science Libraries: Monograph Collections by Computer," in Everett H. Brenner, comp., The Information Age in Perspective, p.44-47. Proceedings of the ASIS Annual Meeting, V.15. White Plains, N.Y.: Knowledge Industry Publications, 1978.

Computer tapes containing holdings of four unspecified health science libraries are analyzed by subject classification.

Brazell, Troy V., Jr. "Comparative Analysis: A Minimum Music Materials Budget for the University Library," College \& Research Libraries 32:110-20 (1971).

Based on a survey of total annual music expenditures and expenditures per FTE student in forty-six U.S. and Canadian university libraries, the author generates three models varying according to the university's enrollment - for a minimum annual music materials budget. 
Broadus, Robert N. "Evaluation of Academic Library Collections: A Survey of Recent Literature," Library Acquisitions: Practice and Theory 1:149-55 (1977).

A number of the best-known collection evaluation methods for academic libraries each of which possesses "difficulties and shortcomings"- are critically analyzed. The author stresses that the need for duplicate copies should be considered in the evaluation process.

Brown, Helen M. "College Library Standards," Library Trends 21:204-18 (1972).

The historical evolution of standards for U.S. college libraries is surveyed from 1929 to the early 1970 s.

Bryan, Harrison. "The Perpetuation of Inadequacy: A Comment on the Atkinson Report," Australian Academic and Research Libraries 7:213-21 (1976).

A report proposing a formula for calculating the maximum size of Australian university library collections is rejected as "dangerous."

Burr, Robert L. "Evaluating Library Collections: A Case Study," Journal of Academic Librarianship 5:256-60 (1979).

The evaluation of the book collection for a six-year planning program at Gonzaga University is described. For each major curriculum area, the number of volumes held was compared to the desired number (according to a modified formula A of the ACRL standards). Next a sampling technique was employed to profile statistically the holdings in each curriculum area.

Carpenter, Ray L. "College Libraries: A Comparative Analysis in Terms of the ACRL Standards," College \& Research Libraries 42:7-18 (1981).

U.S. Office of Education data concerning collections, staff, budget, and services from 1,146 American college libraries is compared with the ACRL's 1975 "Standards for College Libraries." Most libraries do not meet the standards in these four areas.

Cassata, Mary B., and Dewey, Gene L. "The Evaluation of a University Library Collection: Some Guidelines," Library Resources
\& Technical Services 13:450-57 (1969).

Guidelines to be utilized by the bibliographers in conducting comprehensive collection evaluations in discrete subject areas at the State University of New York at Buffalo libraries are outlined. Suggested methods include subjective appraisal, checking bibliographies in scholarly works, and measuring the shelflist.

Craig, Daza Fox, and Strain, Paula Meise. "Analysis of Collection Development at the National Library of Medicine," Bulletin of the Medical Library Association 68:197-206 (1980).

The monographic acquisitions from 1965 to 1977 are analyzed in terms of subject classification, language, and date using CATLINE (the NLM's online computerized cata$\log$ ) data.

Crittenden, V. "The Second Wark Report and the So-Called Standards," Australian Academic and Research Libraries 1:3-4 (1970).

The author believes the standard for Australian college library collections in the Commonwealth Advisory Committee on Advanced Education's second report is unrealistically low.

Day, Richard A.; Bowden, Virginia M.; and Kronick, David A. "Comparison of Holdings of NLM (CATLINE) with Those of Resource Libraries," Bulletin of the Medical Library Association 67:25-30 (1979).

The holdings of the National Library of Medicine, the University of Texas Health Science Center at San Antonio, the University of Texas Medical Branch at Galveston, and the South Central Regional Medical Library Program consortium are compared in four subject areas by means of CATLINE plus three other databases.

Evans, G. Edward. "Collection Evaluation," in his Developing Library Collections, p.234-53. Littleton, Colo.: Libraries Unlimited, 1979.

An overview of the methods used in collection evaluation is offered. The author states that no single method is fully adequate by itself, but all can be helpful when supplemented by other approaches. The chapter 
concludes with a brief summary of steps which can be employed in an evaluation project.

Fernekes, Robert William. "A Study of the Relationship between the Book Collection and the Curriculum at Cleveland State Community College." Ph.D. dissertation, George Peabody College for Teachers, 1974.

The shelflist was employed to determine the number of books supporting each of twenty-three curriculum areas; each area's percentage of the books listed in the 1972 $A B P R$ annual was calculated; and faculty opinion was surveyed. Finally, the data was correlated to determine deficient subject areas.

Forman, Sidney. “One Librarian's View of NCATE 'Standards,'” Teachers College Record 72:519-23 (1971).

The author contends that the standards issued in 1970 by the National Council for Accreditation of Teacher Education are totally inadequate, especially as applied to the education library's collection.

Gardner, Richard K. "Collection Evaluation and Standards," in his Library Collections: Their Origin, Selection and Development, p.233-43. New York: McGrawHill, 1981.

After summarizing the use of statistical measures, list checking, user opinion, direct observation, and applying standards, the author contends no method is better than another.

Golden, Barbara. "A Method for Quantitatively Evaluating a University Library Collection," Library Resources \& Technical Services 18:268-74 (1974). Reprinted in Phyllis Van Orden and Edith B. Phillips, eds., Background Readings in Building Library Collections. 2d ed., p.140-47. Metuchen, N.J.: Scarecrow, 1979.

At the University of Nebraska at Omaha library, LC classification numbers were assigned to every course listed in the university catalog, and the shelflist was checked to determine how many titles support each course. This figure was then compared to the number of students enrolled in the course.

Goldhor, Herbert. “Analysis of an Inductive Method of Evaluating the Book Collection of a Public Library," Libri 23:6-17 (1973).

Instead of checking a bibliography to determine how many titles the library holds, the inductive method entails beginning with a sample of titles (held in the collection) and checking standard bibliographies and reference works to ascertain how many times each title is listed.

Goldstein, Marianne, and Sedransk, Joseph.

"Using a Sample Technique to Describe Characteristics of a Collection," College d Research Libraries 38:195-202 (1977).

This paper presents a statistical sampling technique for describing the fundamental characteristics of a book collection, such as, publication date, country of origin, language, type of publisher, format, and edition.

Gore, Daniel. "Farewell to Alexandria: The Theory of the No-Growth, High Performance Library," in his Farewell to Alexandria, p.164-80. Westport, Conn.: Greenwood, 1976.

Rejecting the contention that an adequate collection must be large, Gore argues that collection adequacy should be judged by performance, i.e., the percentage of time the patron finds the book he wants on the shelf.

Hendricks, Donald D. "Standards for College Libraries," Texas Library Journal 48:74-76 (1972).

This essay outlines the standards on collection size prescribed by a 1969 report of the ACRL-ARL Joint Committee and by the Clapp-Jordan formula. The author concludes that until some future point when library networks can provide physical access to materials, quantitative standards will remain the best method of judging a collection's quality.

Herling, Eleanor B. "Possibility of Quantitative Standards for University Book Collections," in Irene Braden and Alice S. Clark, eds., Quantitative Methods in Librarianship, p.57-60. Contributions in Librarianship and Information Science, no.4. West- 
port, Conn.: Greenwood, 1972.

The utility of then-current standards on collections for college and junior college libraries is questioned because the standards are couched in general terms that do not represent anything measurable. Gross quantitative standards based on estimates of published material would be more helpful.

Hodowanec, George V. "An Acquisition Rate Model for Academic Libraries," College \& Research Libraries 39:439-47 (1978).

Based on the assumption that usage reflects need, data gathered from several hundred U.S. academic libraries was subjected to a twelve-variable correlation and multiple regression analysis to determine which variables influence circulation. Predictive multiple regression equations were used to calculate the recommended yearly acquisition rate in total books as well as books per student.

Holley, Edward G. "The Revision of Standard Six of the College Delegate Assembly of the Southern Association of Colleges and Schools," Southeastern Librarian 26:13-21 (1976).

The 1975 revision of the Southern Association's 1962 library standard is described. The new section on resources recognizes the emergence of multimedia, microform, and nonprint material as a significant part of the collection. The utilization of standard bibliographies and checklists to assess collection quality is recommended.

Holt, Mae L. "Collection Evaluation: A Managerial Tool," Collection Management 3:279-84 (1979).

A number of collection evaluation approaches are briefly surveyed to help library administrators choose the methods that best meet their needs. The author claims an evaluation project should begin by examining the university's goals.

Humphreys, K. W. "Standards for Libraries in Great Britain," Library Trends 21:312-29 (1972).

The author summarizes the current standards or the work completed towards achieving standards for all types of British libraries.
Humphreys, K. W. "Standards in University

Libraries,” Libri 20:144-55 (1970).

Current standards for university libraries in the world's industrial nations are summarized. The author feels that standards on collection size are not related to what figure is required, but rather to what figure the authorities will accept.

Ifidon, Sam E. “Qualitative/Quantitative Evaluation of Academic Library Collections: A Literature Survey," International Library Review 8:299-308 (1976).

Nineteen studies dealing with collection evaluation in academic libraries are abstracted. The author concludes that (1) statistical techniques have established some empirical basis for qualitative evaluation methods; (2) the available standards are based on the "best" practice that is not empirically testable; and (3) analysis of citations is becoming established as a useful method.

Iwasaru, Toshio. "Japanese University Library Standards and Surveys," in Thomas R. Buckman, Yukihisa Suzuki, and Warren M. Tsuneishi, eds., University and Research Libraries in Japan and the United States, p.91-100. Chicago: American Library Assn., 1972.

The post-World War II standards for academic libraries in Japan are analyzed, including the 1953 "principles" for national university libraries as well as 1956 and 1963 statements concerning private universities.

Kronick, David A., and Bowden, Virginia M. "Management Data for Collection Analysis and Development," Bulletin of the Medical Library Association 66:407-13 (1978).

Using computer-generated databases, the collection of the University of Texas Health Science Center at San Antonio is compared with that of the University of Texas Medical Branch and the National Library of Medicine in terms of subject coverage. With respect to currency, the center's collection is compared with that of the National Library of Medicine.

Lancaster, F. W. "Evaluation of Document Delivery," in his Guidelines for the Evaluation of Information Systems and Services, 


\section{p.26-38. Paris: Unesco Press, 1978.}

There are three facets to evaluating a library's ability to provide documents. These are the evaluation of (1) the collection; (2) the catalog; and (3) document delivery. Strategies for conducting each type of evaluation are given.

Lancaster, F. W. "Evaluation of the Collection," in his Measurement and Evaluation of Library Services, p.165-206. Washington, D.C.: Information Resources Press, 1977.

Lancaster discusses three basic approaches to collection evaluation: the quantitative, the qualitative, and evaluation by use. His major emphasis falls on use studies. Numerous summaries of other scholarly investigations are presented.

Lee, James D. “College Libraries: Are 100,000 Volumes Enough?” North Carolina Libraries 33:5-7 (1975).

The author argues against the assertion that an undergraduate library should contain no more and no less than 100,000 volumes.

Line, Maurice B. “The Ability of a University Library to Provide Books Wanted by Researchers," Journal of Librarianship 5:37-51 (1973).

Two surveys were conducted at the University of Bath to determine what follow-up actions faculty members took on bibliographical references they encountered. Thus, one can measure what proportion of potential (as opposed to actual) demand was fulfilled by the library's holdings.

Lopez, Manuel D. “A Guide for Beginning Bibliographers," Library Resources \& Technical Services 13:462-70 (1969).

Numerous techniques for collection evaluation are suggested, including a technique devised by the author for in-depth evaluation of a specific discipline. In the author's technique, references are randomly selected from a critical bibliography and checked against the holdings. After repeating the process through four levels, an 80-40-20-10 scoring system is applied.

Lyle, Guy R. "Evaluation of the College Li- brary," in his Administration of the College Library. 4th ed., p.293-310. New York: Wilson, 1974.

This chapter focuses on the purpose, principles, and procedures of evaluation in college libraries, including the use of standards, statistics, and surveys. It is stressed that quantitative standards can not be used to fully assess a college library book collection.

McDonald, John P. "Academic Library Standards," in Robert D. Stevens, Raynard C. Swank, and Theodore F. Welch, eds., Japanese and U.S. Research Libraries at the Turning Point, p.211-17.

Metuchen, N.J.: Scarecrow, 1977.

The development of standards for U.S. academic libraries is reviewed from the ACRL "Standards for College Libraries" in 1959 through the efforts to devise standards for university libraries in the late 1960s. Particular attention is paid to formulas for collection size.

McElderry, Stanley. "Definitions of Requirements for Undergraduate Programs in University Libraries," in Choong $\mathrm{H}$. Kim, Robert D. Little, and William H. Kurth, eds., Library Management: Quantifying Goals, p.17-34. Terre Haute: Indiana State University, Department of Library Science, 1973.

Numerous methods of quantifying the size of the undergraduate collection in terms of volumes and growth rate are illustrated with complete statistical details.

McInnis, R. Marvin. "The Formula Approach to Library Size: An Empirical Study of Its Efficacy in Evaluating Research Libraries," College \& Research Libraries 33:190-98 (1972).

Linear regression analysis is employed to evaluate the Clapp-Jordan formula using data from the thirty-six largest Ph.D.granting graduate schools in the U.S. If the formula errs, it errs in underestimating the required number of books.

McInnis, R. Marvin. "Research Collections: An Approach to the Assessment of Quality," IPLO Quarterly 13:13-22 (1971).

McInnis proposes that research collections be evaluated by checking citations taken 
from a random sample of currently published research in a single discipline against the library's holdings. The "scientific" approach as well as the low cost of implementation are offered as justification.

Manning, D. J. "Collection-Building and Recurrent Expenditure Criteria for Teachers' College Libraries," Australian Academic and Research Libraries 1:33-49 (1970).

Formulas for minimal total holdings and yearly expenditures are proposed for teacher college libraries in Australia. The most intriquing takes the arithmetic mean of the Clapp-Jordan formulas for two-year and four-year colleges to derive a standard for three-year colleges.

Massman, Virgil F., and Patterson, Kelly. "A Minimum Budget for Current Acquisitions," College \& Research Libraries $31: 83-88$ (1970).

It is contended that standards for current book acquisition rates in college libraries should be based on book production and the curriculum, rather than on the number of students, as in the 1959 ACRL standards for college libraries.

Meek, L. "Student Success Rates at Macquarie University Library," Australian Academic and Research Libraries 9:33-36 (1978).

Students were asked to complete questionnaires as they left the library to determine how often they found the books they sought. The staff subsequently sample-checked nonlocated titles to ascertain if they were held.

Mitchell, Ruth Kay. "A Methodology for Assessing Academic Library Collection Development." Ph.D. dissertation, Univ. of Pittsburgh, 1976.

The Clapp-Jordan formula is applied to the Oregon State University Library and then extended to include price factors. After comparisons with other libraries, the extended formula is proposed as a general evaluation tool.

Moran, Michael. "The Concept of Adequacy in University Libraries," College \& Research Libraries 39:85-93 (1978).
Moran contends that, according to logical and linguistic analysis, the concept of adequacy cannot be meaningfully applied to a university library collection.

Mosher, Paul H. "Collection Evaluation in Research Libraries: The Search for Quality, Consistency and System in Collection Development," Library Resources \& Technical Services 23:16-32 (1979).

This work outlines the history of collection evaluation in American university libraries beginning with the 1933 University of Chicago survey. A collection evaluation program at Stanford in which graduate students are hired to do bibliographical checking is discussed in detail.

Mosher, Paul H. "Collection Evaluation or Analysis: Matching Library Acquisitions to Library Needs," in Robert D. Stueart and George B. Miller, Jr., eds., Collection Development in Libraries, p.527-45. Foundations in Library and Information Science, V.10, part B. Greenwich, Conn.: JAI Press, 1980.

Mosher presents a general overview of collection evaluation, with summaries of the major approaches and steps to be taken in conducting an evaluation.

Mostyn, Gregory R. "The Use of SupplyDemand Equality in Evaluating Collection Adequacy," California Librarian 35:16-23 (1974).

Intended for public libraries, the technique propounded here compares a subject area's percentage of total books in the collection (measured by the shelflist), i.e., supply, with the percentage of total circulations (based on statistical samples), i.e., demand.

Murray, Florence B. "Canadian Library Standards," Library Trends 21:298-311 (1972).

The development of standards for public, school, and university libraries in Canada from the 1930 s to the early 1970 s is summarized. The author concludes that Canadian library standards have been short-lived because they contribute to the development of new objectives that require revised standards. 
Nisonger, Thomas E. "Collection Evaluation: Nine Techniques Discussed in the Literature," Manitoba Library Association Bulletin 11, no.1:18-20 (1980).

Nine specific methods for collection evaluation are recapitulated. The author notes that it is always possible to devise one's own evaluation method instead of relying on those previously published.

Nisonger, Thomas E. “An In-Depth Collection Evaluation at the University of Manitoba Library: A Test of the Lopez Method," Library Resources \& Technical Services 24:329-38 (1980).

An experimental testing of the Lopez method is described. Inconsistencies in the results raise questions about the technique's reliability, although the technique does evaluate the collection's depth.

Orr, Richard H., and Schless, Arthur P. "Document Delivery Capabilities of Major Biomedical Libraries in 1968: Results of a National Survey Employing Standardized Tests," Bulletin of the Medical Library Association 60:382-422 (1972).

Sophisticated statistical analyses are applied to the results of administering Orr's document-delivery test in ninety-two U.S. medical school libraries. The authors develop a model for ascertaining a library's "virtual" capacity (what it can provide the user) as distinct from its "basic" capacity (what it holds).

Penner, Rudolf Jacob. "Measuring a Library's Capability . . . ," Journal of Education for Librarianship 13:17-30 (1972).

The capability index of Orr's documentdelivery test-previously used only in biomedical libraries - was experimentally implemented in two library school libraries. It was concluded that Orr's device is also applicable to this field.

Power, Colleen J., and Bell, George H. “Automated Circulation, Patron Satisfaction, and Collection Evaluation in Academic Libraries-A Circulation Analysis Formula," Journal of Library Automation 11:366-69 (1978).

The authors offer a formula, developed at the Arizona State University Library, which uses automated circulation statistics to determine the required number of volumes per faculty member as well as per graduate and undergraduate student. To implement the method, one must first ascertain through a survey that users are satisfied with the present collection.

Radford, Neil A. “Academic Library Surveys Prior to 1930," Journal of Library History, Philosophy and Comparative Librarianship 8:150-58 (1973).

Nine early surveys of U.S. academic libraries (Harvard, Dominion College, Iowa State, Rollins, Battle Creek, Union Theological Seminary, University of Denver, Marygrove, and Rosary) are described.

Robbins-Carter, Jane; Anderson, Elaine K.; and Chinn, H. Diggins, III. State of Wyoming Library Effectiveness Measurement Kit. Cheyenne: Wyoming State Library, 1976.

This kit is intended to assist all types of libraries in Wyoming with self-evaluations. The collection is evaluated using an ad hoc checklist of 119 books plus 14 journal titles.

Rose, Priscilla. "Innovation and Evaluation of Libraries and Library Services," Drexel Library Quarterly 7:28-41 (1971).

The need for research methods to evaluate innovation in libraries is stressed. Five datagathering techniques are summarized: (1) experiments; (2) models; (3) case studies; (4) comparative statistics; and (5) surveys.

Rosenberg, Betty. "Evaluation: Problems of Criteria and Methodology," California Librarian 38:17-21 (1977).

The methodological difficulties inherent in several standard approaches to collection evaluation are discussed, with emphasis on their shortcomings. The best evaluation tool is an experienced and intelligent librarian "preferably with a sense of humor."

Routh, Spencer. "Evaluating the Collection," Australian Special Libraries News 9:11-18 (1976).

This general discussion begins with a distinction between explicit demands on the collection and true needs, and ends with a list of ten collection evaluation exercises. 
Ruttakorn, Lamoon. "Adequacy of Book Collections in Seven School of Education Libraries of Srinakharinwirot University." D.L.S. dissertation, Univ. of Southern California, 1976.

The educational monographic collection of Srinakharinwirot University (in Thailand) was evaluated through questionnaires to faculty as well as undergraduates. Statistics were compiled and reading lists plus other checklists were compared against the holdings. Also, faculty were asked to rate the usefulness of titles randomly selected from the shelflist.

Schofield, J. L.; Cooper, A.; and Waters, D. H. "Evaluation of an Academic Library's Stock Effectiveness," Journal of Librarianship 7:207-27 (1975).

A "failure survey" was conducted at an unspecified British university library. More than 1,000 patrons were interviewed as they left the library to analyze why they failed to obtain needed books. The proportion of failures due to (1) titles not held, (2) titles not available, and (3) reader failure was ascertained.

Sineath, Timothy Wayne. "The Relationship between Size of Research Library Collections and the Support of Faculty Research Studies." Ph.D. dissertation, Univ. of Illinois, 1970.

To determine the correlation between the size of a university library collection and its ability to support research, citations from faculty publications at universities with large library collections (Michigan and Illinois) were checked against the holdings of their own library, the other large library, and a smaller one (Colorado State). The two large collections supported the research of each other's faculty equally well, and both supported their faculties' research better than did the collection of the small library.

Snowball, George J. "Evaluation of an Academic Library Collection by Reference to Three Standards for Size," CACUL Newsletter 3:120-41 (1971).

The size of the collection at Sir George Williams University in Montreal is compared to the required levels specified by the ClappJordan formula, the Washington State for- mula, and the CACUL (Canadian Association of College and University Libraries) standard.

Stevens, Norman D. "Three Early Academic Library Surveys," College \& Research Libraries 30:498-505 (1969).

Early surveys of the Rutgers University, Williams College, and Beloit College libraries are analyzed.

Strayer, Marcia S. "A Creative Approach to Collection Evaluation," IPLO Quarterly 13:23-28 (1971).

Strayer asserts that citation checking represents a creative method of collection evaluation. Several variations are discussed, including possible computer applications. Because it measures quality, the citation checking method is considered an improvement over quantitative methods.

Stubbs, Kendon. "University Libraries: Standards and Statistics," College of Research Libraries 42:527-38 (1981).

Various statistical techniques (ratio, regression, discriminant and principal component analyses) are applied to ARL and ACRL data for 196 university libraries, which are rank-ordered according to composite data for ten variables, such as total holdings, volumes added, expenditures, etc. Stubbs concludes that derived minimal levels seem "very much like quantitative standards."

Swank, Raynard C. "Evaluation of American University Libraries," in Thomas R. Buckman, Yukihisa Suzuki, and Warren M. Tsuneishi, eds., University and $R e$ search Libraries in Japan and the United States, p.82-91. Chicago: American Library Assn., 1972.

This paper analyzes the use of surveys as a technique for evaluating American university libraries. Four methods of conducting surveys are depicted: (1) the historical; (2) the descriptive; (3) scientific management; and (4) the experimental.

Texas Library Association. Library Development Committee. Subcommittee on Standards for Senior College and University Libraries. "Report," Texas Library Journal 46:28-29 (1970). 
The report recommends for Texas academic library collections a modified version of the quantitative standards contained in the 1965 Higher Education Act.

Tjarks, Larry. "Evaluating Literature Collections," RQ 12:183-85 (1972).

Following a brief review of a selected number of formulas for academic library collections, a bibliography is included which lists sources that can be utilized as checklists to evaluate the holdings in English and American language and literature.

Totten, Herman L. "Traditionally Black Texas Colleges' Libraries and ACRL Standards," Texas Library Journal 45:205-7, 247-48 (1969).

Data are tabulated from a questionnaire sent in July 1969 to the eight black college libraries in Texas (seven responded) to ascertain to what extent they met the ACRL "Standards for College Libraries" in regard to staff and resources.

Trueswell, Richard W. "Growing Libraries: Who Needs Them? A Statistical Basis for the No-Growth Collection," in Daniel Gore, ed., Farewell to Alexandria, p.72-104. Westport, Conn.: Greenwood, 1976.

Statistics demonstrating that a small percentage of the holdings account for most of the circulation are used to question the assumption that a good academic library must be large.

Turner, Frank L. "Quality Not Numbers," Arkansas Libraries 30:8-9 (1974).

After describing the status of academic libraries in Arkansas, Turner asserts that "volume count" can no longer be the sole criterion for measuring a collection's adequacy.

Voigt, Melvin J. “Acquisition Rates in University Libraries," College \& Research Libraries 36:263-71 (1975).

Based on the assumption that, for university research libraries, the current acquisition rate is more significant than total collection size, a model for determining the acquisition rate of current material for university libraries supporting Ph.D. programs is proposed.
Watkins, David R. "Standards for University Libraries," Library Trends 21:190-203 (1972).

The problems encountered in various attempts to establish standards for U.S. university libraries are reviewed.

Webb, William. "Project CoED: A University Library Collection Evaluation and Development Program," Library Resources \& Technical Services 13:457-62 (1969).

In phase one of this project at the University of Colorado libraries, the holdings in medieval studies, art history, political science, physics, and Slavic studies were surveyed by sample-checking bibliographies. In phase two, standard bibliographies were checked in entirety to fill gaps in U.S. and British social and literary history.

Wenger, Charles B., and Childress, Judith. "Journal Evaluation in a Large Research Library," Journal of the American Society for Information Science 28:293-99 (1977).

For a journal evaluation project at the $\mathrm{Na}$ tional Oceanic and Atmospheric Administration Library in Boulder, Colorado, the authors devised a "balance index" that correlates usage with shelf space. In addition, the standard journal evaluation techniques were used.

Wenger, Charles B.; Sweet, Christine B.; and Stiles, Helen J. "Monograph Evaluation for Acquisitions in a Large Research Library," Journal of the American Society for Information Science 30:88-92 (1979).

A computer was utilized at the National Oceanic and Atmospheric Administration Environmental Research Laboratories Libraries to compare circulation with inventory for specific LC call numbers (minus the author Cutter).

Whaley, John H., Jr. “An Approach to Collection Analysis," Library Resources \& Technical Services 25:330-38 (1981).

In this approach faculty members mark, on an LC classification table for a subject, the courses corresponding with each class and provide keywords describing their courses, which are then linked through LC subject headings back to the classification ta- 
ble. The shelflist is consulted to determine the number of volumes supporting each course so that deficiencies can be remedied.

White, G. Travis. "Quantitative Measures of Library Effectiveness," Journal of Academic Librarianship 3:128-36 (1977).

Numerous quantitative methodologies for library assessment are analytically summarized, including the Clapp-Jordan formula, Voigt's acquisitions model, Orr's documentdelivery system, Goldhor's "inductive method," and Mostyn's "supply-demand" model.

Williamson, Marilyn L. "Serials Evaluation at the Georgia Institute of Technology Library," The Serials Librarian 2:181-91 (1977).

A fifteen-space field on the Faxon Company's computerized list of 4,000 Georgia Tech periodical subscriptions was used to record data. Based on usage, accessibility, availability, cost, and format, each title was placed in one of five categories, ranging from "essential" to "irrelevant."

Withers, F. N. Standards for Library Service. Paris: Unesco Press, 1970.

Academic, school, and public library standards in numerous countries (with emphasis on Europe and the Anglo-American democracies) are summarized and compared. Withers notes that standards written for one nation often influence the development of standards in another.

Withers, F. N. Standards for Library Service: An International Survey. Documentation, Libraries and Archives: Studies and Research, no.6. Paris: Unesco Press, 1974.

An expanded version of the author's 1970 study, this extensive monograph surveys the current standards covering virtually all aspects of library service in more than twenty countries. 